\title{
COMUNICAÇÃO
}

\section{MULTIPLICAÇÃO IN VITRO DE OLIVEIRA (Olea europaea L.)}

\author{
Olive (Olea europaea L.) in vitro multiplication
}

\author{
Leonardo Ferreira Dutra ${ }^{1}$, Adelson Francisco de Oliveira ${ }^{2}$, Chrystiane Borges Fráguas ${ }^{3}$, Moacir Pasqual ${ }^{4}$
}

\section{RESUMO}

Com o objetivo de induzir a multiplicação em explantes de oliveira, segmentos nodais oriundos de plântulas mantidas in vitro foram excisados e inoculados em tubos de ensaio contendo meio de cultura MS suplementado com $2 \mathrm{~g} \mathrm{~L}^{-1}$ de carvão a-

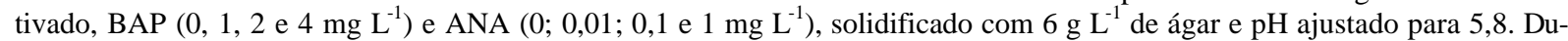
rante 100 dias, os explantes foram mantidos em sala de crescimento a $25 \pm 1^{\circ} \mathrm{C}$, intensidade luminosa de $32 \mu \mathrm{moles} . \mathrm{m}^{-2} . \mathrm{s}^{-1} \mathrm{e}$ fotoperíodo de 16 horas. Não houve indução de brotações nos segmentos nodais. O maior comprimento da parte aérea foi obtido com $0,1 \mathrm{mg} \mathrm{L}^{-1}$ de ANA na ausência de BAP. O meio de cultura sem BAP proporcionou maior peso de matéria fresca da parte aérea.

Termos para indexação: Cultivo in vitro, proliferação, segmentos nodais, BAP, ANA.

\section{ABSTRACT}

This work had the objective to induce olive multiplication. Nodal segments from in vitro plantlets were excised and inoculated in test tubes containing MS culture medium supplemented with activated charcoal $\left(2 \mathrm{~g} \mathrm{~L}^{-1}\right), \mathrm{BAP}(0,1,2 \mathrm{and} 4 \mathrm{mg}$ $\left.\mathrm{L}^{-1}\right)$, NAA $\left(0 ; 0.01 ; 0.1\right.$ and $\left.1 \mathrm{mg} \mathrm{L}^{-1}\right)$, agar $\left(6 \mathrm{~g} \mathrm{~L}^{-1}\right)$ and $\mathrm{pH}$ adjusted to 5.8. The explant were maintained in growth room to $25 \pm 1^{\circ} \mathrm{C}, 32 \mu$ moles. $\mathrm{m}^{-2} . \mathrm{s}^{-1}$ light intensity and 16 hours photoperiod for 100 days. There was not shoots induction in the nodal segments. Larger length of aerial part were obtained with ANA $0.1 \mathrm{mg} \mathrm{L}^{-1}$ in the BAP absence. Culture medium without BAP provides larger weight of fresh matter of the aerial part.

Index terms: In vitro culture, proliferation, nodal segment, BAP, NAA.

(Recebido para publicação em 31 de março de 2003 e aprovado em 15 de agosto de 2003)

A oliveira, em nível comercial, é propagada vegetativamente por enxertia e estaquia. A propagação por sementes não é aconselhável em função da variabilidade genética e longo período juvenil, além da baixa germinação em condições de campo, inviabilizando a propagação comercial. Entretanto, pode ser utilizada na produção de porta-enxertos de cultivares difíceis de enraizar por estacas e em programas de melhoramento genético (CAÑAS et al., 1992).

No Brasil, a propagação da oliveira por enxertia utilizando como porta-enxerto o ligustro (Ligustrum sp.) foi utilizada com freqüência (FERNANDES, 1985). Entretanto, como pertencem a gêneros distintos, problemas de incompatibilidade entre enxertos e portaenxertos são verificados. Hartmann et al. (1986) observaram incompatibilidade entre oliveira e diversos porta-enxertos e mesmo com porta-enxertos de outras espécies do gênero Olea.
Outra alternativa é a propagação por meio de estacas lenhosas, atualmente o método mais empregado. No entanto, a viabilidade da estaquia está condicionada a inúmeros fatores, que propiciam grande variabilidade no enraizamento (ABOUSALIM et al., 1993; RKHISS e TRIGUI, 1996).

Em vista disso, a cultura de tecidos pode ser uma prática viável para a propagação da oliveira. Diversos métodos e meios para obter plântulas de oliveira in vitro, oriundas de diferentes explantes, foram desenvolvidos com êxito (SEYHAN e OZZAMBAK, 1994a,b; MENCUCCINI, 1995; LEITÃO et al., 1997; OLIVEIRA, 2001). Entretanto, tem sido relatado que a oliveira possui forte dominância apical. Standardi et al. (1998) afirmaram que a proliferação da oliveira se dá predominantemente por alongamento.

As citocininas e auxinas são os reguladores de crescimento mais importantes para a regulação do

1. Pós-Doutorando/CNPq, Universidade Federal de Lavras/UFLA, Caixa Postal 37 - 37200-000 - Lavras, MG. leodutra@ufla.br

2. EPAMIG - CTSM, Caixa Postal 176 - 37.200.000, Lavras, MG. adelson@epamig.ufla.br

3. Aluna do Programa de Pós-Graduação em Fitotecnia da UFLA.

4. Professor Titular do Departamento de Agricultura/UFLA. mpasqual@ufla.br 
crescimento e da morfogênese de tecidos e órgãos (PASQUAL, 2001). Citocininas induzem a quebra da dominância apical e proliferação de gemas axilares. Dessas, a benzilaminopurina (BAP) tem sido muito eficaz na multiplicação de explantes e indução de gemas adventícias, além de ser mais barata do que outras citocininas (GRATTAPAGLIA e MACHADO, 1998). As auxinas são muito utilizadas na micropropagação para promover a formação e o crescimento de calos, de órgãos e de células em suspensão, bem como regular a morfogênese, especialmente quando associada com citocininas. Um adequado balanço entre auxinas e citocininas estabelece um eficiente controle no crescimento e na diferenciação das culturas in vitro (PIERIK, 1990).

Objetivou-se com este trabalho avaliar o efeito de concentrações de BAP e ácido naftalenoacético (ANA) na indução de brotações laterais em microestacas de oliveira.

O trabalho foi desenvolvido no Laboratório de Cultura de Tecidos Vegetais, do Departamento de Agricultura, Universidade Federal de Lavras (UFLA), em Lavras/MG.

Segmentos nodais de aproximadamente $2 \mathrm{~cm}$, sem folhas, foram excisados de plântulas de oliveira 'Ascolano 315', oriundas de cultura de embriões, e inoculados assepticamente em meio MS (MURASHIGE e SKOOG, 1962), suplementado com $30 \mathrm{~g} \mathrm{~L}^{-1}$ de sacarose, $2 \mathrm{~g} \mathrm{~L}^{-1}$ de carvão ativado, solidificado com $6 \mathrm{~g} \mathrm{~L}^{-1}$ de ágar e ajustado para $\mathrm{pH} 5,8$ antes da autoclavagem. $\mathrm{O}$ meio de cultura foi autoclavado a $121^{\circ} \mathrm{C}$ e 1 atm durante 20 minutos.

Foram testadas as combinações dos reguladores $\operatorname{BAP}\left(0,1,2\right.$ e $\left.4 \mathrm{mg} \mathrm{L}^{-1}\right)$ e ANA $\left(0 ; 0,01 ; 0,1\right.$ e $\left.1 \mathrm{mg} \mathrm{L}^{-1}\right)$, com 3 repetições constituídas por 4 frascos cada uma. Os explantes foram inoculados individualmente em tubos de ensaio e transferidos para sala de crescimento com temperatura de $25 \pm 1^{\circ} \mathrm{C}$, intensidade $1 \mathrm{u}$ minosa de $32 \mu$ mol. $\mathrm{m}^{-2} . \mathrm{s}^{-1}$ e 16 horas de fotoperíodo. Após 100 dias nessas condições de cultivo, avaliaram-se o número e o comprimento de brotos e a matéria fresca da parte aérea. $O$ delineamento experimental foi inteiramente casualizado, em esquema fatorial 4 x 4 (4 níveis de BAP e 4 níveis de ANA). Os resultados foram submetidos à análise estatística e os tratamentos, comparados por regressão polinomial.

Não houve efeito dos reguladores de crescimento no número de brotos, observando-se somente a alteração no crescimento em altura do único broto desenvolvido, indicando a dificuldade em se induzir brotações em oliveira. Esse resultado corrobora as afirmações de Cañas et al. (1987) e Standardi et al. (1998), de que a oliveira possui forte dominância apical, proliferando predominantemente por alongamento.

Maior comprimento de brotos foi obtido com 0,1 $\mathrm{mg} \mathrm{L}^{-1}$ de ANA na ausência de BAP (Figura 1). À medida que se aumentou a concentração de BAP, houve redução nessa variável, provavelmente em função de desbalanço hormonal. Quando se adicionou $1 \mathrm{mg} \mathrm{L}^{-1} \mathrm{de}$ ANA combinado com $3,1 \mathrm{mg} \mathrm{L}^{-1}$ de BAP, praticamente duplicou-se o comprimento de brotos. Nesse caso, estabeleceu-se um balanço entre auxina/citocinina mais adequado. Não houve significância das concentrações de 0 e $0,01 \mathrm{mg} \mathrm{L}^{-1}$ de ANA.

Maior matéria fresca da parte aérea foi obtida na ausência de BAP (Figura 2), com subseqüente redução à medida que se aumentou a concentração desse regulador de crescimento. Essa resposta provavelmente é devida a um desbalanço na relação au$\mathrm{xina} /$ citocinina.

A ausência de resposta dos reguladores de crescimento na indução de brotações corrobora resultados anteriores obtidos com cultivo in vitro de oliveira (CAÑAS et al., 1987; STANDARDI et al., 1998), verificando-se somente o crescimento em altura da brotação. Em vista disso, é necessário o estudo de alternativas, no intuito de induzir a proliferação de maior número de brotações em oliveira. Como o BAP não foi efetivo nas concentrações utilizadas, sugere-se a possibilidade da utilização de concentrações maiores. Outra possibilidade é o emprego de outras citocininas, a exemplo de zeatina, 2iP (2isopentenil adenina) e TDZ (Thidiazuron), preferencialmente as duas últimas, em razão do elevado custo da zeatina. 


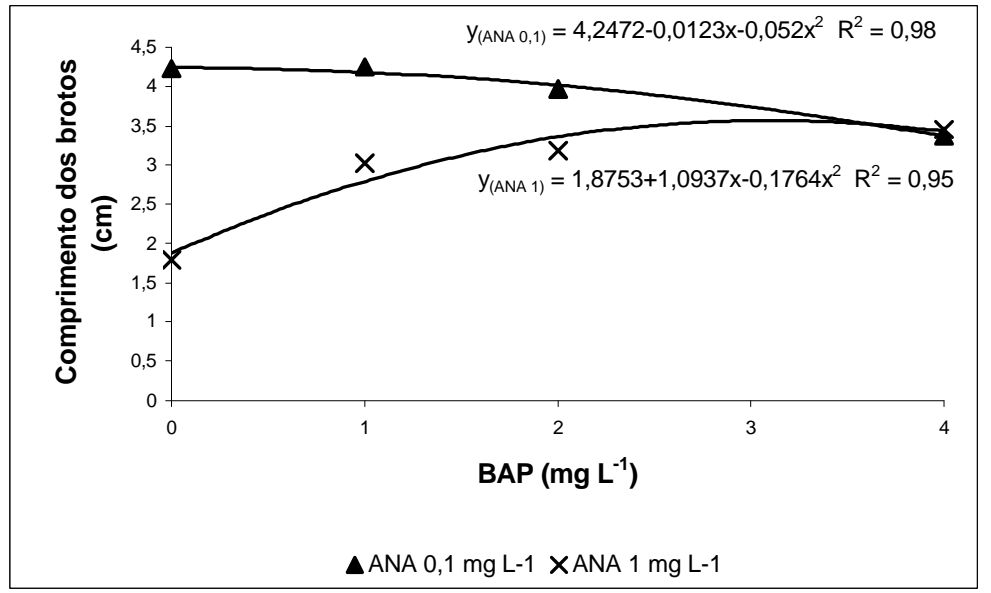

FIGURA 1 - Comprimento das brotações em segmentos nodais de oliveira cultivados em meio de cultura MS sob diferentes concentrações de BAP e ANA. UFLA, Lavras, 2002.

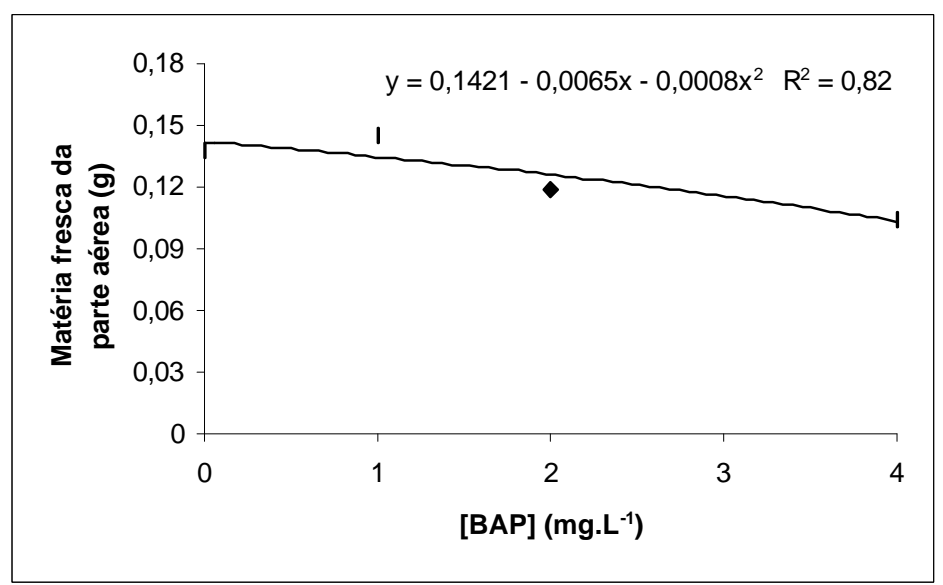

FIGURA 2 - Matéria fresca da parte aérea em segmentos nodais de oliveira cultivados em meio de cultura MS sob diferentes concentrações de BAP e ANA. UFLA, Lavras, 2002.

\section{REFERÊNCIAS BIBLIOGRÁFICAS}

ABOUSALIM, A.; WALALI, L. D. M.; SLAQUI, K. Efecto de la fase fenológica sobre el enraizamento de las estaquillas semileñosas del olivo en tablillas termógenas. Olivae, Madrid, n. 46, p. 30-37, 1993.

CAÑAS, L. A.; AVILA, J.; VICENTE, M.; BENBADIS, A. Micropropagation of Olive (Olea europaea L.). In: BAJAJ, Y. P. S. (Ed.). Biotechnology in agriculture and forestry: high-tech and micropropagation II. Berlin: Springer-Verlag, 1992. p. 493-505. v. 18.

CAÑAS, L. A.; CARRAMOLINO, L.; VICENTE, M. Vegetative propagation of the olive tree from in vitro cultured embryos. Plant Science, Limerick, v. 50, p. 85-90, 1987.

FERNANDES, E. D. A enxertia da Oliveira (Olea europaea L.) sobre Ligustro (Ligustrum ovaliform Hassk). Porto Alegre: Secretaria da Indústria e Comércio, $1985.17 \mathrm{p}$. 
GRATTAPAGLIA, D.; MACHADO, M. A. Micropropagação. In: TORRES, A. C.; CALDAS, L. S.; BUSO, J. A. Cultura de tecidos e transformação genética de plantas. Brasília: CBAB/EMBRAPA-CNPH, 1998. p.183-260.

HARTMANN, H. T.; OPITE, K. W.; BENTEL, J. A. La producción oleicola en california. Olivae, Madrid, v. 3, n. 11, p. 24-65, 1986.

LEITÃO, L.; DUQUE, A. S.; FEVEREIRO, P. Cultivo in vitro de variedades portuguesas de Olea europaea L.: objetivos e resultados. Olivae, Madrid, v. 66, p. 54$55,1997$.

MENCUCCINI, M. Micropropagazione e miglioramento genetico in vitro dell'olivo: stato dell'arte e prospettive future. Rivista di Frutticoltura, Bolonha, n. 12, p. 73-82, 1995.

MURASHIGE, T.; SKOOG, F. A revised medium for rapid growth and bioassays with tobacco tissue cultures. Physiologia Plantarum, Copenhagen, v. 15, n. 6, p. 473 479, 1962.

OLIVEIRA, A. F de. Enraizamento de estacas semilenhosas e cultura de embriões in vitro de oliveira (Olea europaea L.). 2001. 122 p. Tese (Doutorado em
Fitotecnia) - Universidade Federal de Lavras, Lavras, 2001.

PASQUAL, M. Meios de cultura: cultura de tecidos vegetais: tecnologia e aplicações. Lavras: UFLA/FAEPE, 2001. 74 p.

PIERIK, R. L. M. Preparación y composición de los medios nutritivos. In: Cultivo "in vitro" de las plantas superiores. Madrid: Mundi Prensa, 1990. p. 49-84.

RKHISS, A. C.; TRIGUI, A. El estaquillado semileñoso de la variedad Chemlali de Sfax: dificuldades y posibilidades de mejora. Olivae, Madrid, n. 61, p. 46$52,1996$.

SEYHAN, S.; OZZAMBAK, E. Cultivo de tejidos de dos variedades de olivo turcas. Olivae, Madrid, v. 52, p. 28-29, 1994a.

SEYHAN, S.; OZZAMBAK, E. Shoot multiplication of some olive (Olea europaea) cultivars. Acta Horticulturae, Wageningen, n. 356, p. 35-38, 1994 b.

STANDARDI, A.; MICHELI, M.; PICCIONI, E. Propagaziione "in vitro" dell'olivo: acquisizione e prospettive. Rivista di Frutticoltura, Bolonha, n. 7/8, p. 19-23, 1998. 